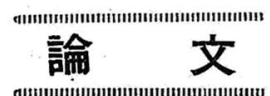

\title{
岩石の衝撃曲げ試験についで*
}

\author{
平松良雄** 西原正夫炈岡 行 俊****新 堀 義 門****
}

\section{Impact Flexure Tests of Rocks}

\section{Yoshio Hiramatsu, Masao Nishinara, Yukitoshi Oka and Yoshikado NiIHori}

According to many reports published on the impact strength of rocks, the Page impact test is usually adopted, while the impact flexure test is seldom used.

The authors have designed a Charpy-type flexure testing machine with a small impact energy, $0.02 \mathrm{~kg} \cdot \mathrm{m}$, in order to make it possible to test such a brittle material as rock, and have carried out the tests with this machine on sandstone, marble and granite.

The results obtained show that this method affords a possible means of determining the impact strength of rocks.

\section{1. 序 論}

岩石の脆さの程度を知るため反従来 Page 衝撃試験

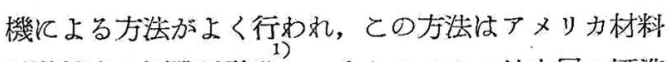
試験㶸会の標準試験法飞, またアメリカ鉱山局の標準 試験法に採用されている。との試験方法は四筒形の試 験片上飞重錘を落下させて㣫揧を与党る方法で，その 高さを順次增して，ちようぞ試験片が破壤する高さを 求め, その高さを試験片の断面積で除した值をむつて その勒脆をあらわすととになつている。との方法で最 も心配されるのは試験片の破壞が認められる以前と, すで微小知目が発生しているかも知れないととで ある。とれに対して Charpy 試験のよう記試験片に打 揧を与完材料の破壊飞要する仕事を測定与る方法では

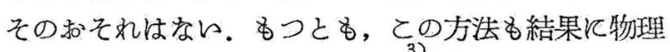
的意嶬が之しいとされてはいるが, 上記の長所がある ので岩石材料につトてとの種の衝撃試験を試みた。

\section{2. 試験方法および試験機}

岩石の上うふ脆性材料では衝撃破䬉の際の吸収エネ ルギーが小さいから, 衝撃エネルギーの小さに試験機 を使用しなければならない。そてで衝撃エネルギーが 金属材料の Charpy 試験の場合の $25 \mathrm{~kg} \cdot \mathrm{m}$ まをは $30 \mathrm{~kg} \cdot \mathrm{m}$ とらのに比べてはるが小さい約 $0.02 \mathrm{~kg} \cdot \mathrm{m}$ の試験機老作つて用的た。との試験機恃本多・佐藤式
高温衝揧硬度計を一部改造したもので，Fig. 1 亿示す ようである。試験片の寸法は金属材料のCharpy.試験 飞使用するもの(JIS B 7703) と同し $10 \mathrm{~mm} \times 10 \mathrm{~mm}$

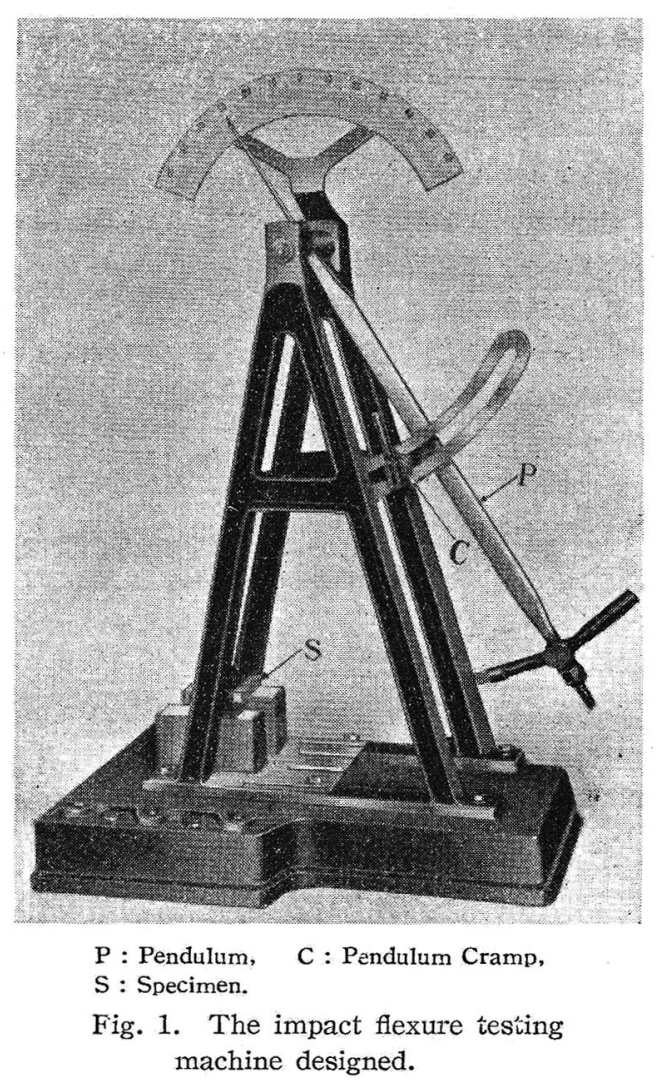


$\times 55 \mathrm{~mm}$ としたが，金属の試験の場合のような切欠 は作らなかつた。その理由は金属に执いても踌鉄のよ ら飞脆々材料を試験する場合には切欠のある試験片よ りも，ないものの方がよ結果を与えるとされている から, 性質の脆岩石では切火を作らなくてさしつか えないでろらと考えられ，また試験片製作技術からみ て岩石の試験片に正確に切欠を作るととが困難である からである。試験方法もCharpy 試験と同様とした。 吸収エネルギー $E$ は次式により計算した。

$$
E=G l(\cos \beta-\cos \alpha)
$$

ここに， $G$ は振子の重さ $\mathrm{kg}, l$ は振子の回転軸から 重心までの距離 $\mathrm{m}, \alpha$ は振子の持上げ角で $30^{\circ}, \beta$ は 振子の振上り角である。

\section{3. 試}

料

試料としては成因も機诫的性質も大々反異なる大理 石, 砂岩, 就よ゙花崗岩の 3 種類の岩石をえらんだ. 和の和の産地は次のようである。

大理石：山口県美㼛郡於福台座

砂 岩: 大阪府泉南郡淡の輪産で和泉砂岩と称す る 80

花崗岩：愛知県額田郡真福寺村産

それぞれの岩石から10個の試験片を作り，その中 5 個は乾懆試料として室内に放置し, 歹戋りの5 俱は湿潤 試料として蒸溜水に 24 時間浸した後試験に供した。 吸水率は乾燥試料と湿潤試料の重さの差から求めた。

\section{4. 試 験 '結 果}

上記の30個の試験片を試験してえられた振上り角扣 よび(1)式から求めた吸収ェネルギーを示すとTable 1 の通りとなる、金属のCharpy 試験では吸収ェネルギ 一を切欠部の有効断面積で除した值を衝撃值として, 衝撃に対する強さを比較する尺度としているが，乙れ はあまり意味がないようであるから，とこでは吸収エ ネルギーを求めるに止めた。 また吸収エネルギーの差

Table 1. Angle of rise of pendulum and calculated energy absorption (angle of fall $=30^{\circ}$ ).

\begin{tabular}{|c|c|c|c|c|c|c|c|c|}
\hline \multirow{2}{*}{\multicolumn{2}{|c|}{ Specimen }} & \multicolumn{2}{|c|}{ Marble } & \multicolumn{2}{|c|}{ Sandstone } & \multicolumn{2}{|c|}{ Granite } & \multirow{2}{*}{$\begin{array}{l}\text { Free } \\
\text { swing }\end{array}$} \\
\hline & & dry & wet & dry & wet & dry & wet & \\
\hline \multirow{6}{*}{$\begin{array}{c}\text { Angle } \\
\text { of } \\
\text { rise }\end{array}$} & & $24 \cdot 7$ & $24^{\circ} 0$ & $23 \cdot 3$ & $22 \cdot 7$ & $23 \cdot 7$ & $21 \cdot 3$ & $28 \cdot 1$ \\
\hline & Observ- & $22 \cdot 7$ & $24 \div 5$ & $24 \cdot 6$ & $22 \cdot 6$ & $22 \cdot 6$ & $21 \cdot 7$ & $27 \cdot 8$ \\
\hline & ed & $23 \cdot 7$ & $24 \cdot 1$ & $23 \cdot 2$ & $22 \cdot 6$ & $23 \cdot 6$ & $21 \cdot 6$ & $26 \cdot 5$ \\
\hline & & $25 \cdot 3$ & $24 \cdot 4$ & $25 \cdot 1$ & $21 \cdot 7$ & $22 \cdot 3$ & $22 \cdot 6$ & $27 \cdot 2$ \\
\hline & (degree) & $25 \cdot 9$ & $24 \cdot 4$ & $22 \cdot 2$ & $22 \cdot 8$ & $23 \cdot 5$ & $24 \cdot 4$ & 28.1 \\
\hline & Mean & $24 \cdot 46$ & $24 \cdot 28$ & \begin{tabular}{|l|}
$323 \cdot 68$ \\
$\mid$
\end{tabular} & $22 \cdot \frac{1}{28}$ & $23 \cdot 14$ & $22 \cdot 32$ & $27 \cdot 54$ \\
\hline \multicolumn{2}{|c|}{$\begin{array}{c}\text { Energy } \\
\text { absorpted } \\
(\mathrm{kg} \cdot \mathrm{m})\end{array}$} & $\mid \begin{array}{l}4 \cdot 05 \\
\times 10^{-3}\end{array}$ & $\begin{array}{l}4 \cdot 27 \\
\times 10^{-3}\end{array}$ & $3 \begin{array}{c}5 \cdot 01 \\
\times 10^{-3}\end{array}$ & $\begin{array}{l}6 \cdot 43 \\
\times 10^{-3}\end{array}$ & $\begin{array}{l}5.62 \\
\times 10^{-3}\end{array}$ & $\begin{array}{c}6.60 \\
\times 10^{-3}\end{array}$ & \\
\hline
\end{tabular}

の検定には振子の振上り角を用いて行うことにした。

さて, との結果に基づいてわれわれの試験方法によ つて衝撃破壞によるエネルギー吸取を検知できるか, またできるとすれば試料の乾湿の違らによつて吸収 エネルギーの差が認められるかてついて検討を試み た。振子の振上り角を比較してみると, 最も振上り角 の大きい大理石の乾燥試料の場合でも信頼度 $99 \%$ その差を認めるととができる。しかし岩石の種類によ る差が認められない限りとの試験の意義は少ないか ら, この点について検尌すると, 湿潤大理石と湿潤花 崗岩とは分散比が大きいために, 信頼度 $99 \%$ 以上で同 一正規母集団の無作意標本ではないとみなしらるか ら, 対応のない場合の差の検定はできない.しかし， 乙れら以外のものは差の検定が可能であつて, 湿潤大 理石と湿潤砂岩は信頼度 $99 \%$, 乾燥大理石と乾燥花崗 岩は信頼度 $95 \%$ 差を認めるととができる。これに詨 乙て乾燥大理石と乾燥砂岩, 乾燥砂岩と乾燥花崗岩, 湿潤砂岩と湿潤花崗岩は信頼度 $95 \%$ だ差を認める ことができない。したがつて，われわれの試験法で大 体岩石試料による吸収エネルギーを検知できたものと 考えられる。

次に乾湿の違いによる差について考えれば,との検 定は刘応のある場合に相当し; いすれれの試料について も, その差は信頼度 $95 \%$ では認められないが, 90\%で は砂岩に扣いて認められ，75\%では花崗岩で認めら れ, 大理石では認められない。

\section{5. 結論}

前節の検定に和いて述べをように, 岩石の種類によ り衝撃強さの差を認めにくらものああるが,一応との 試験によれば衝撃に封する強さは大理石, 砂岩, 花崗 岩の順に大をくなつて和り, 乾湿の状態による差は認 めにくかつた。しかし湿潤試料は蒸溜水に24時間漫 したものであるから飽和していない恐れがあり,さら に長時間浸しそ場合飞差があらわれるととも考えられ る.とのととは吸水率の最も大きい砂岩に和吸收 エネルギーの差が最も大きいととからも手想される。

重錘落下式の.Page 衝擊試験機によつて, Obert, Windes, Duvall らが岩石の衝撃強さを調べている. その結果と今回の衝撃曲げ試験の結果と沬試験方法や その他の条件が異なつているので值接比較の対象とは なりにくいが, かれらの結果によれば, 衝撃強さは砂 岩, 大理石, 花崗岩の順に大きくなり, また乾燥した ものでは衝撃强さ在増している。乾湿による衝撃強さ の変化については，かれらは压縮試験の場合について 吸水によつて強さが低下するととを確認し, 曲げ試験 の場合にはこの影響を検討する必要なしとして実験を 行つていない.

昭和 30 年 5 月 
また衝撃曲げ試験と静的曲げ試験との結果を比較し てみるとは同庫の試験とよるのが最も望ましく, 現在 準備中である。四筒状試験片について Obert らが行 つを絓果によると, 岩石の曲げ破壊係数 (modulus of rupture)将岩, 大理石, 花崗岩の順に大きく, か礼 らの行つた Page 衝撃試験の結果と同順てなつている.

まを衝撃試験片の破面の状態から材料の勒脆の程度 を判別するととは，金属の場合飞はある程度可能のよ

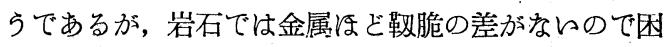
難と思われる。

実験飞協力さ祃を京大工学部鉱山学教室段野教官, 佐竹大学院学生, ならびて試験装置について援助され
そ京大工学部機峨教室に対し謝意を表する。

* 曲げ破壞係数 Rは次式であらわされる.ただし $P$ は破壊荷重, $l$ は支点間距離， $d$ は試騟片の直径である，

$$
R=\frac{8 P l}{\pi d^{3}}
$$

注: 一

1) ASTM, Designation D 3-18, ASTM Standards, Part II, p. 427 (1942)

2) Report of Investigation, No. 3891, U.S. Bureau of Mines, p.p. 41 45 (1946)

3) M. Freudenthal, The Inelastic Behaviour of Engineering Materials and Structures, London, pp. $555 \sim 559^{\circ}$ (1950)

4) ibid. 2), pp. $43 \sim 45$

5) ibid. 2), pp. $23 \sim 26$

\title{
引抜材の機械的性質に関する研究*
}

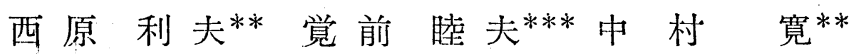

\section{Experimental Research on Mechanical Properties of Drawn Wire}

\section{Toshio Nishinara, Mutsuo Kakuzen and Hiroshi Nakamura}

This parer deals with the experimental research on the effects of change of wire drawing condition on hardness distribution over the section of drawn wire.

Using a Micro-Vickers hardness tester, we tried to investigate the hardness distribution over the cross section of three kinds of carbon steel wires and a brass wire, drawn under several kinds of drawing conditions, as well as the gradual change of hardness over the longitudinal section of carbon steel wires under plastic deformation with half drawn specimen.

As the results we have make it clear that the wire with uniform deformation as possible will be obtained by following methods of drawing:

(1) with the die of larger radius of curvature of drawing surface than with the die of smaller radius,

(2) under high reduction of diameter than low reduction.

\section{1. 緒言}

引拢条件が線材の個々の機械的性質に及㳊す影響に 関しては従来種々の研究がなされているが，引拢条件 と線材の機械的諸性質との総合的な関保についてはを だあまり明らかにされて和らず，鈴木弘氏の研究があ るに過をないような状態である。

われわれはさきに二次曲線ダイスについて引抜応力 の計算式を導き，数值計算により引抜条件が引抜応力

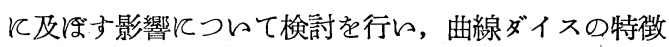

\footnotetext{
* 原稿受付 昭和 30 年 2 月 9 日 日本材料試験拹会第 3 期䌊会に 扎てて满演

** 正員 京都大学

$* * *$ 正員 同志社大学
}

を明らかにし,さらに引抜応力の計算飞必要な引抜時 飞和ける摩擦保数の值を測定し，乙れを用的て引拢㐫 力の計算結果が実際の值とよく一致するととを実験的 そ確かめたのであるが，諸種の条件のもとに引抜いた 線材について機找的諸性質を測定し, 引拢条件がこれ

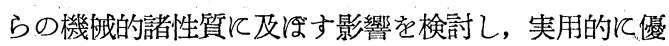
れを性質をもつた線材を得るための引抜条件を求好る ととを目的として行う研究のうち, 本文では線材の硬 度に及深す引抜条件の影響を明らかにするために行つ そ実験につレて報告する。

\section{2. 引抜線材の硬度分布}

ダイスによつて線材が引抜かれる場合, 線材が不均 